\title{
Thyrotropin-releasing hormone (TRH) is not thyrotropic but somatotropic in fed and starved adult chickens *
}

\author{
ER Kühn ${ }^{1 * *}, M$ Herremans 3 , E Dewil 1, \\ A Vanderpooten 1, P Rudas 2, T Bartha 2,3, \\ G Verheyen 3, L Berghman 4, E Decuypere 3
}

\author{
1 Catholic University of Leuven, Zoological Institute, Laboratory of Comparative Endocrinology, \\ Naamsestraat 61, B-3000 Leuven; \\ 2 University of Veterinary Science, Department of Physiology, Budapest Pf 2, H-1400 Hungary; \\ 3 Catholic University of Leuven, Laboratory for Physiology of Domestic Animals, \\ Kardinaal Mercierlaan 92, B-3030 Heverlee; \\ ${ }_{4}$ Catholic University of Leuven, Laboratory for Neuroendocrinology \\ and Immunological Biotechnology, Naamsestraat 59, B-3000 Leuven, Belgium
}

(Received 12 December 1990; accepted 25 March 1911)

\begin{abstract}
Summary - Adult fed and starved Warren chickens, 2 yr of age, and approaching the end of the second laying year, were injected iv with 1 of the following products: $10 \mu \mathrm{g}$ of thyrotropin releasing hormone (TRH); $100 \mu \mathrm{g}$ of bovine thyrotropin (bTSH); $100 \mu \mathrm{g}$ of ovine growth hormone (oGH); saline. The influence on plasma concentrations of thyroxine $\left(T_{4}\right)$, trilodothyronine $\left(T_{3}\right)$ or chicken $G H$ (cGH) were followed. Prior to injection, it was clear from the control values that starvation for $3 \mathrm{~d} d e-$ creased plasma levels of $T_{3}$ and increased $c G H$, whereas $7 \mathrm{~d}$ of fasting increased $T_{4}$ and $c G H$. The plasma levels of $\mathrm{cGH}$ were elevated $>10$-fold at $15 \mathrm{~min}$ following the TRH challenge in fooddeprived chickens compared to a $<4$-fold increase in normal fed hens. This increase was followed by a rise in $T_{3}$ after $1 \mathrm{~h}$, which was also more pronounced in the starved animals, whereas $T_{4}$ decreased or remained unaffected. Increases in $T_{4}$ can, however, be obtained with $100 \mu \mathrm{g} \mathrm{TSH}$ in normal fed (2-fold) or starved animals (> 3-fold). Following injection of $100 \mu \mathrm{g} \mathrm{oGH}$, a significant increase in $T_{3}$ levels was observed which in fed animals was already present at 30 min, but the higher levels persisted for 1 and $2 \mathrm{~h}$ in fed and starved hens. At the same time, a decrease in $\mathrm{T}_{4}$ was observed in both groups of GH-treated chickens. It is concluded that TRH at the dose used is not thyrotropic but has a somatotropic effect and is responsible for the peripheral conversion of $T_{4}$ into $T_{3}$.
\end{abstract}

TRH / thyrotropic / somatotroplc / chicken

Résumé - La thyréolibérine (TRH) n'est pas thyréotrope mais somatotrope chez la poule adulte, nourrie ou à jeun. Des poules Warren, nourries ou à jeun, âgées de 2 ans ou à la fin de leur deuxième année de ponte, ont reçu une injection intraveineuse de l'un des produits suivants :

\footnotetext{
* These results were presented at the 15th Conference of European Comparative Endocrinologists, 9-14 September 1990, Leuven, Belgium

** Correspondence and reprints
} 
$10 \mu g$ de thyréolibérine synthétique (TRH), $100 \mu g$ d'hormone thyréotrope bovine (bTSH), $100 \mu g$ d'hormone somatotrope ovine (oGH) ou du serum physiologique. Les concentrations plasmatiques en thyroxine $\left(T_{4}\right)$, triiodothyronine $\left(T_{3}\right)$ et hormone de croissance $(\mathrm{cGH})$ ont été étudiées à lissue de ces traitements. Un jeûne de 3 jours a fait baisser le taux de base de $T_{3}$ circulante et augmenter celui de $c G H$, alors qu'un jeûne de 7 jours a élevé ces taux pour $T_{4}$ et $c G H$. Chez les poules à jeun, les niveaux plasmatiques de cGH ont été au moins 10 fois plus élevés 15 min après linjection de TRH qu'après celle de serum physiologique; chez les animaux nourris, cette augmentation est restée inférieure à 4 fois. Dans tous les cas, la stimulation de cGH a été suivie d'une augmentation des taux sanguins de $T_{3}, 1 \mathrm{~h}$ après l'injection - elle est aussi plus importante chez les poules à jeun - alors que $T_{4}$ a diminué ou n'a pas varié. Par contre, $T_{4}$ s'est élevée après l'injection de TSH aussi bien chez les poules nourries $(x 2)$ que celles à jeun ( $x$ 3 ou plus). L'injection de oGH a provoqué une élévation significative des taux de $T_{3}$, visible dès 30 min chez les poules nourries; elle a persisté pendant 1 et $2 \mathrm{~h}$ chez les poules nourries et à jeun. Inversement, $T_{4}$ a diminué dans les deux groupes d'animaux soumis à ce traitement. En conclusion, TRH, aux doses utilisées, n'est pas thyreotrope mais somatotrope chez la poule adulte chez qui elle est responsable de la conversion périphérique de $T_{4}$ en $T_{3}$.

TRH / thyréotrope / somatotrope / poule

\section{INTRODUCTION}

In all vertebrates except fishes, the hypothalamic tripeptide thyrotropin-releasinghormone (TRH) is known to release thyrotropin (TSH) from the hypophysis, which will affect both release and synthesis of triiodothyronine $\left(T_{3}\right)$ and thyroxine $\left(T_{4}\right)$. Consequently, plasma concentrations of these hormones are raised in response to $\mathrm{TRH}$, though the major bulk of circulating $T_{3}$ is derived from peripheral monodeiodination of $T_{4}$ (Licht and Denver, 1990).

An injection of TRH in the chick embryo (Kühn et al, 1988) and in growing chickens (Michels et al, 1986) increases plasma concentrations of both $\mathrm{T}_{4}$ and $\mathrm{T}_{3}$. Although, at least for the chick embryo, the rise in $T_{3}$ may also be the result of a stimulated peripheral conversion of $T_{4}$ into $T_{3}$ by $\mathrm{GH}$, which is released simultaneously with TSH in response to TRH (Scanes et al, 1985). However, in the adult chicken different doses of TRH increase plasma $\mathrm{T}_{3}$ but not $T_{4}$, which may even be decreased (Kühn et al, 1988). This suggests that in adult chickens, although the thyroid is still responsive to $\mathrm{TSH}$ stimulation, $\mathrm{TRH}$ is not thyrotropic but only able to stimulate the peripheral conversion of $T_{4}$ into $T_{3}$ by its somatotropic effect.

This aspect of thyroid physiology has been reinvestigated in the following study on adult chickens in direct relation to the release of $\mathrm{GH}$. Since food deprivation is known to increase the responsiveness of the hypophysis for $\mathrm{GH}$ release and to affect thyroid hormone levels (Harvey, 1990), the influence of food deprivation on plasma concentration of $\mathrm{GH}$ and thyroid hormones following TRH stimulation was also included in this study.

\section{MATERIALS AND METHODS}

Chickens used in these experiments were adult Warren SSL (2.5 kg, age $2 \mathrm{yr}$ ) approaching the end of the second laying year. They were housed under standard temperature $\left(20^{\circ} \mathrm{C}\right)$ and light conditions (16 $L-8 D$ ). Both fed and fooddeprived hens ( 3 and 7 d) had free access to tap water. In the first experiment, saline and TRH (10 $\mu$ g; UCB, Belgium), were injected into a wing vein and blood samples were taken from 
this vein in heparin just before injections and after $15 \mathrm{~min}, 1 \mathrm{~h}$ and $2 \mathrm{~h}$. This experiment was replicated (called exp 1i throughout the text). In the second experiment saline, ovine $\mathrm{GH}(100$ $\mu \mathrm{g}$; NIADDH, NIH, MD) and bovine TSH (100 $\mu g$; Sigma) was injected into a wing vein and blood samples were taken from the wing vein after $30 \mathrm{~min}, 1 \mathrm{~h}$ and $2 \mathrm{~h}$.

Chicken $\mathrm{GH}$ (cGH) as purified from a crude pituitary extract using monoclonal antibodies was used for the homologous $\mathrm{GH}$ radioimmunoassay (RIA) (Berghman et al, 1988). The $T_{3}$ and $\mathrm{T}_{4}$ concentrations in plasma were assayed by using tracer obtained from Amersham International (UK), rabbit $T_{3}$ antiserum from Mallinckrodt (Germany) and a laboratory-raised rabbit $\mathrm{T}_{4}$ antiserum. This $T_{4}$ antiserum had a $0.16 \%$ cross-reactivity with $\mathrm{T}_{3}$. All RIAs had good parallelism with plasma dilution curves, an intraassay variability of $<5 \%$ and an interassay variability of $<10 \%$.

Statistical analyses of the results were performed by a $t$-test for paired data, and analyses of variance and covariance with polynomials fit- ted through the repeated measurements (SAS, 1985).

\section{RESULTS}

\section{Control values}

Plasma concentrations of $T_{3}, T_{4}$ and cGH were not altered in fed and food-deprived chickens following saline injections (paired $t$-test) up to $2 \mathrm{~h}$ following injections. Preinjection, basal control values for these hormones in fed and food-deprived chickens are summarized in table I. In both experiments, $T_{4}$ and $C G H$ plasma concentrations were increased after $7 \mathrm{~d}$ of food deprivation, whereas $T_{3}$ was decreased in one experiment after $3 \mathrm{~d}$ and in the other after $7 \mathrm{~d}$.

Table I. Control values for plasma concentrations of $T_{3}, T_{4}$ and $c G H(n g / m l \pm S E M)$ in normal fed and food deprived chickens.

Normal fed 3-d fasted 7-d fasted

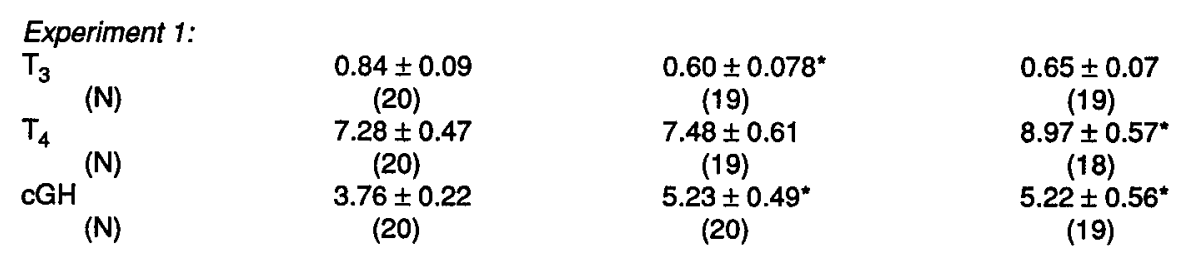

Experiment 2:

$\begin{array}{lccc}T_{3} & 1.14 \pm 0.08 & 0.87 \pm 0.05^{* *} \\ T_{4} & (N) & (30) & (30) \\ & (N) & 8.10 \pm 0.66 & 12.33 \pm 0.41^{* * *} \\ \text { CGH } & (N) & 2.97 \pm 0.11 & (30) \\ & (N) & (30) & 4.72 \pm 0.63^{* *}\end{array}$

ANOVA * $P<0.05 ; * * P<0.01 ;{ }^{* * *} P<0.001$ compared to normal fed animals. 


\section{Postinjection values}

\section{TRH injection (exp 1 and 1i)}

Following TRH injection plasma concentrations of $\mathrm{CGH}$ were increased after $15 \mathrm{~min}$. The increase of $\mathrm{cGH}$ was much more pronounced in food-deprived ( $>10$-fold) compared to fed hens $(<4$-fold) and resulted in a significant interaction between feed and treatment at $15 \mathrm{~min}$ and $1 \mathrm{~h}$ (table II). $\mathrm{T}_{3}$ increased in normal fed and food-deprived animals after 1 and $2 \mathrm{~h}$. The increase in $T_{3}$ after $2 \mathrm{~h}$ varied between 1.5-fold in normal fed chickens and up to 2.2-fold in chickens which had been food-deprived for $7 \mathrm{~d}$. This difference is significant after adjusting for the zero time values by covariation. A small but significant decrease in $T_{4}$ was observed in fed and starved chickens 15 $\min$ and $2 \mathrm{~h}$ after TRH injections. Covariation for zero time level indicates that this decrease was more pronounced in chickens fed ad libitum.

In a repetition of the first experiment, comparable results were obtained (fig 1). However, the interaction between feed and treatment regarding $T_{3}$ increase was much more pronounced in exp 1i, even without covariation for zero time values $(P<$ $0.0001)$. Two $h$ after TRH injection the increase in $T_{3}$ was 2-fold in fed hens, but 3and $>4$-fold at $3 \mathrm{~d}$ and $7 \mathrm{~d}$ respectively in starved chickens. The observed decrease in $T_{4}$ following $T R H$ administration was less pronounced in this instance, as a significant decrease was seen only in fed animals after $2 \mathrm{~h}$. Basal $\mathrm{cGH}$ values did not differ between fed and starved chickens. There was no significant response of GH

Table II. Analysis of variance (with polynomials for repeated measurements). Influence of an injection of $10 \mu \mathrm{g}$ TRH versus saline (= Treat) on the time dynamics of plasma concentrations of $T_{3}, T_{4}$ and GH in normal fed, and 3- and 7-d starved chickens (= Feed) (Exp 1).

\begin{tabular}{|c|c|c|c|c|c|c|c|}
\hline & \multicolumn{4}{|c|}{ Main effects } & \multicolumn{3}{|c|}{ Interactions } \\
\hline & $\begin{array}{l}\text { Feed } \\
(F)\end{array}$ & $\begin{array}{c}\text { Treat } \\
(T r)\end{array}$ & $\begin{array}{l}\text { Time } \\
\text { (Ti) }\end{array}$ & $F \times T r$ & $F \times T i$ & $\operatorname{Tr} \times T i$ & $F \times \operatorname{Tr} \times \pi$ \\
\hline $\begin{array}{l}\mathrm{T}_{3} \text { general } \\
\text { Zero time } \\
15 \mathrm{~min} \\
1 \mathrm{~h} \\
2 \mathrm{~h} \\
\mathrm{~T}_{4} \text { general } \\
\text { Zero time } \\
15 \mathrm{~min} \\
1 \mathrm{~h} \\
2 \mathrm{~h} \\
\mathrm{GH} \text { general } \\
\text { Zero time } \\
15 \text { min } \\
1 \mathrm{~h} \\
2 \mathrm{~h}\end{array}$ & $\begin{array}{c}N S \\
N S \\
N S \\
N S \\
N S \\
0.04 \\
N S \\
N S \\
0.03 \\
N S \\
<0.0001 \\
=0.022 \\
=0.0002 \\
<0.0001 \\
=0.014\end{array}$ & $\begin{array}{c}<0.0001 \\
N S \\
N S \\
<0.0001 \\
<0.0001 \\
N S \\
N S \\
N S \\
N S \\
N S \\
<0.0001 \\
N S \\
<0.0001 \\
<0.0001 \\
N S\end{array}$ & $\begin{array}{c}<0.0001 \\
- \\
- \\
- \\
- \\
<0.0001 \\
- \\
- \\
- \\
- \\
<0.0001 \\
- \\
- \\
- \\
-\end{array}$ & $\begin{array}{l}N S \\
N S \\
N S \\
N S \\
N S \\
N S \\
N S \\
N S \\
N S \\
N S \\
0.042 \\
N S \\
=0.011 \\
=0.0015 \\
N S\end{array}$ & $\begin{array}{c}0.06 \\
- \\
- \\
- \\
\overline{N S} \\
- \\
- \\
- \\
- \\
=0.003 \\
- \\
- \\
- \\
-\end{array}$ & $\begin{array}{c}<0.0001 \\
- \\
- \\
- \\
- \\
0.003 \\
- \\
- \\
- \\
- \\
<0.0001 \\
- \\
- \\
- \\
-\end{array}$ & $\begin{array}{c}\text { NS } \\
- \\
- \\
- \\
\overline{-} \\
\text { NS } \\
- \\
- \\
- \\
- \\
=0.0014 \\
- \\
- \\
- \\
-\end{array}$ \\
\hline
\end{tabular}




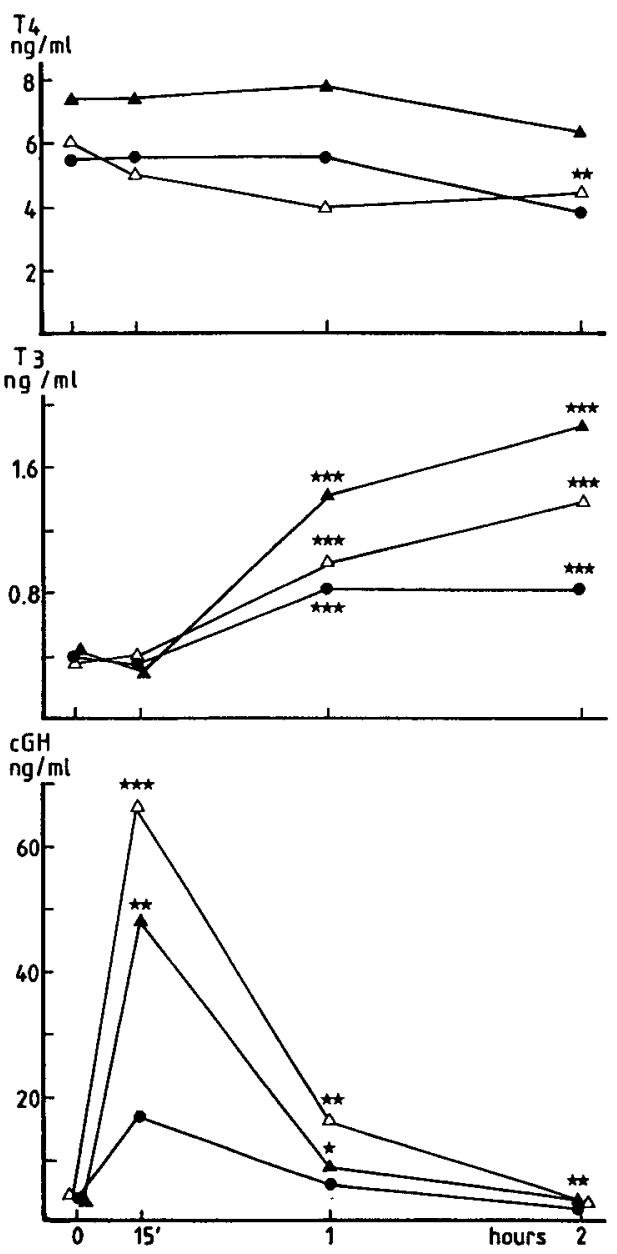

Fig 1. Influence of an injection at zero time of $10 \mu \mathrm{g}$ TRH on plasma concentrations (ng) of $T_{3}$, $\mathrm{T}_{4}$ and cGH in adult chickens $(n=10)$ normally fed $(0)$ and food deprived chickens for $3 d(\Delta)$ or 7 days $(\mathbf{A}) . P<0.05 ;{ }^{* *} P<0.001$ paired $t$-test (exp 1i).

to TRH in fed animals. However, in starved chickens the $\mathrm{cGH}$ increase was 18-fold higher 15 min after TRH injection and remained significant for at least up to $1 \mathrm{~h}$.

\section{TSH and GH injection (fig 2, $\exp 2)$}

A significant increase in $T_{3}$ levels was observed following injection of $100 \mu \mathrm{g} \mathrm{oGH}$ which was evident as early as $30 \mathrm{~min}$ in fed animals and was maintained at $1 \mathrm{~h}$ and $2 \mathrm{~h}$ in fed and starved hens. Saline and TSH did not have any effect on $T_{3}$ in fed chickens. However, in starved hens TSH induced a small increase in $T_{3}$ after 1 and $2 \mathrm{~h}$. A small decrease in $\mathrm{T}_{4}$ after $2 \mathrm{~h}$ was observed in all $\mathrm{GH}$-treated chickens. The increase in $\mathrm{T}_{4}$ at $2 \mathrm{~h}$ following injection of TSH was more pronounced in starved chickens (> 3-fold) than in fed birds (2-fold) (table III).

\section{DISCUSSION AND CONCLUSION}

These results confirm previous observations made both in adult layers $(0.5-10 \mu \mathrm{g} /$ $\mathrm{kg}$ ) and adult broiler hens $(1.5-24 \mu \mathrm{g} / \mathrm{kg})$, ie that a physiological dose of TRH is not thyrotropic as judged by plasma concentrations of $\mathrm{T}_{4}$ (Kühn et al, 1988, 1989), but a secretagogue for $\mathrm{GH}$ at every dose used. As a secondary effect, $\mathrm{GH}$ increases peripheral $\mathrm{T}_{3}$ production. The results are not in contradiction with the earlier work of Klandorf et al (1978) who noted only a very small (1.3-fold) and short-lived increase in $\mathrm{T}_{4}$ using an extremely high amount of TRH $( \pm 75 \mu \mathrm{g} / \mathrm{kg})$ in an adult layer strain, whereas a 2.3-fold increase in $T_{3}$ was observed which lasted for $>3 \mathrm{~h}$.

However, the observed increase in plasma $T_{3}$ and simultaneous decrease in $T_{4}$ following TRH administration leaves open the possibility of TSH secretion and consequently $\mathrm{T}_{4}$ release, which is immediately converted into $T_{3}$. This hypothesis can be ruled out, since a recent study has indicated that no change in $T_{4}$ occurs after TRH administration in adult dwarf hens who lack $\mathrm{GH}$ receptors and therefore are unable to 

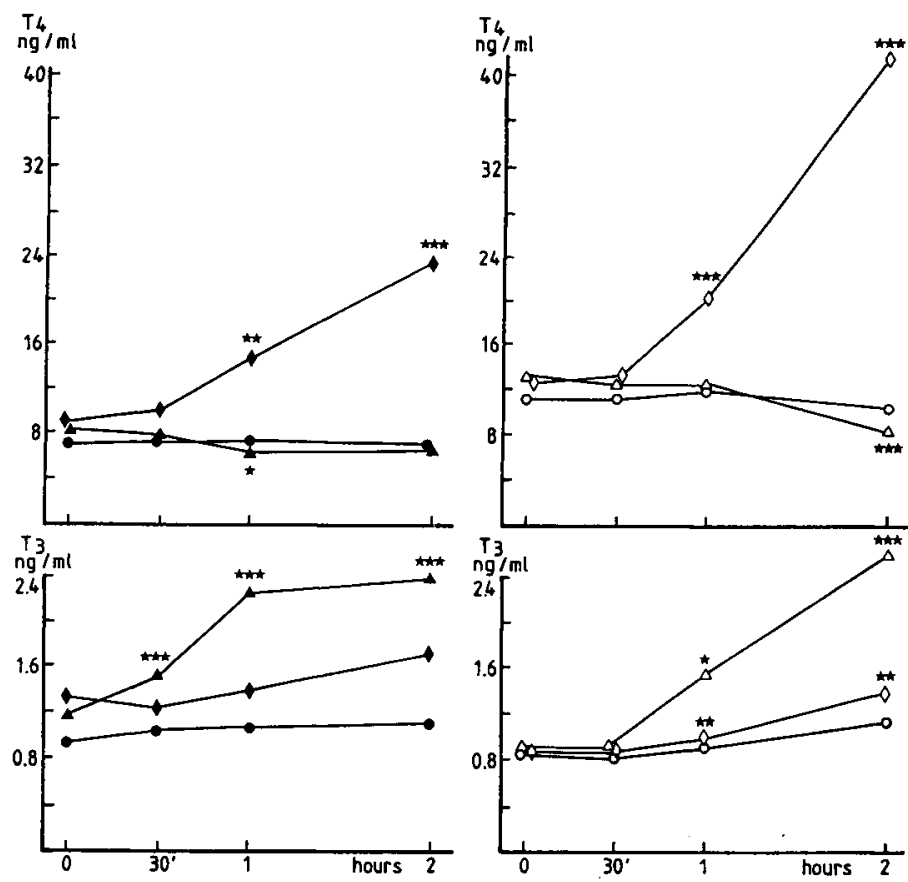

Fig 2. Influence of an injection at zero time of saline ( 0 ), $100 \mu \mathrm{g} \mathrm{bTSH}(\bullet)$ ) or $100 \mu \mathrm{g} \mathrm{oGH}(\Delta \Delta)$ on plasma concentrations (ng) or $\mathrm{T}_{3}$ and $\mathrm{T}_{4}$ in normal fed (closed marks) or food deprived chickens for $7 \mathrm{~d}$ (open marks) ${ }^{\star} P<0.05 ; P<0.01 ;{ }^{\star \star \star} P<0.001$ paired $t$-test $(\exp 2)$.

show a GH mediated conversion of $\mathrm{T}_{4}$ into $T_{3}$. On the other hand, in this experiment $\mathrm{T}_{4}$ decreased in normal hens following TRH stimulation. Moreover, the stimulation of $\mathrm{T}_{4}$ release by TSH is so dramatic in the present experiment that a much more pronounced increase in $\mathrm{T}_{3}$ should be detectable.

These results are therefore in contrast with observations made in embryos (Kühn et al, 1988) or growing chickens (Michels et al, 1986) that TRH is thyrotropic and increases $T_{4}$ together with $T_{3}$. In dwarf embryos (Kühn et al, 1990) or dwarf chicks
(Michels et al, 1986) who are unable to convert $\mathrm{T}_{4}$ into $\mathrm{T}_{3}$ due to a lack of $\mathrm{GH}$ receptors, plasma $T_{3}$ concentrations are not increased following the TRH challenge but the $T_{4}$ release is normal.

The observation that food deprivation lowers plasma concentrations of $\mathrm{T}_{3}$ and increases $\mathrm{T}_{4}$ (May, 1978; Decuypere and Kühn, 1984; Kühn et al, 1987) and GH (Harvey et al, 1988), has been confirmed in this study. It is also known that a hypothyroid state or food restriction (Lauterio and Scanes, 1988; Harvey et al, 1988) promotes TRH-induced $\mathrm{GH}$ secretion, which 
Table III. Analysis of variance (with polynomials for repeated measurements). Influence of an injection of $100 \mu \mathrm{g} \mathrm{TSH}, 100 \mu \mathrm{g}$ oGH or saline (= Treat) on the time dynamics of plasma concentrations of $\mathrm{T}_{3}$ and $\mathrm{T}_{4}$ in normal fed, and 3- and 7-d starved chickens (= Feed) (Exp 2).

\begin{tabular}{|c|c|c|c|c|c|c|c|}
\hline & \multicolumn{3}{|c|}{ Main effects } & \multicolumn{4}{|c|}{ Interactions } \\
\hline & $\begin{array}{l}\text { Feed } \\
\text { (F) }\end{array}$ & $\begin{array}{l}\text { Treat } \\
(T r)\end{array}$ & $\begin{array}{c}\text { Time } \\
\text { (Ti) }\end{array}$ & $F \times T r$ & $F \times T i$ & $\operatorname{Tr} \times T i$ & $F \times \operatorname{Tr} \times \pi$ \\
\hline$T_{3}$ general & $=0.016$ & $<0.0001$ & $<0.0001$ & NS & $=0.009$ & $<0.0001$ & NS \\
\hline Zero time & $=0.007$ & NS & - & NS & - & - & - \\
\hline $15 \min$ & $<0.0001$ & 0.02 & - & NS & - & - & \\
\hline $1 \mathrm{~h}$ & $=0.009$ & $<0.0001$ & - & NS & - & - & - \\
\hline $2 \mathrm{~h}$ & NS & $<0.0001$ & - & NS & - & - & - \\
\hline $\mathrm{T}_{4}$ general & $<0.0001$ & $<0.0001$ & $<0.0001$ & NS & $=0.04$ & $<0.0001$ & $<0.0001$ \\
\hline Zero time & $<0.0001$ & NS & - & NS & - & - & - \\
\hline $15 \mathrm{~min}$ & $<0.0001$ & $=0.05$ & - & NS & - & - & - \\
\hline $1 \mathrm{~h}$ & $<0.0001$ & $<0.0001$ & - & NS & - & - & - \\
\hline $2 h$ & $<0.0001$ & $<0.0001$ & - & $=0.002$ & - & - & - \\
\hline
\end{tabular}

is confirmed in our study, suggesting that $\mathrm{GH}$ release in the adult chicken is partly under tonic thyroidal inhibition. However, in the present study circulating levels of $\mathrm{T}_{3}$ are not consistently decreased following food deprivation, which is in agreement with the observation that prolonged starvation $(7 \mathrm{~d})$ results in increased $\mathrm{T}_{3}$, suggesting a reactivation of the peripheral monodeiodination after a certain period of starvation (Verheyen et al, 1983). Moreover, plasma $\mathrm{T}_{4}$, which can inhibit $\mathrm{GH}$ release in the growing hen (Harvey, 1990) is increased in this study during food deprivation, but apparently unable to inhibit TRHinduced $\mathrm{GH}$ release.

It has been claimed that food deprivation can remove somatostatin inhibition on $\mathrm{GH}$ release and therefore promotes TRHinduced $\mathrm{GH}$ release (Lauterio and Scanes, 1988). However, no change in GH response was observed, following hGRF challenge in chicks following somatostatin neutralization (Buonomo et al, 1987). It has also been shown that somatostatin ad- ministration decreases $\mathrm{T}_{4}$ release in the fowl (Lam et al, 1986; lqbal et al, 1989). This at least would explain why in our study TSH administration provoked a much more pronounced increase in plasma concentration of $T_{4}$ in starved than in fed chickens.

Regardless, no thyrotropic effect of TRH on $\mathrm{T}_{4}$ can be demonstrated; particularly after prolonged food deprivation, the GH response to TRH and TSH-induced $\mathrm{T}_{4}$ release is dramatically increased.

However, the question remains as to why TRH is unable to stimulate the release of TSH in the adult chicken. It has been shown that in the chick more TRH receptors are present in the caudal lobe of the pituitary, which is primarily composed of somatotropes, than in the cephalic lobe, to which the thyrotropes are confined (Harvey and Baidwan, 1989). Apparently the TRH dose needed to stimulate the release of $T_{4}$ is at least 50 times greater than that which provokes $\mathrm{GH}$ release and peripheral $\mathrm{T}_{3}$ production in the adult chicken (see 
above). It is therefore possible that other hypothalamic factors may control the release of thyroid hormones from the thyroid, as has been demonstrated in amphibians (Denver, 1988; Jacobs et al, 1988) or in the chick embryo (Meeuwis et al, 1989).

\section{ACKNOWLEDGMENTS}

E Dewil and A Vanderpooten are supported by the Instituut tot Aanmoediging van het Wetenschappelijk Onderzoek in Nijverheid en Landbouw (IWONL); LR Berghman and $M$ Herremans are senior research assistants of the Belgian Nationaal Fonds voor Wetenschappelijk Onderzoek (NFWO). We wish also to thank $F$ Voets, L Noterdaeme and W Van Ham for valuable technical assistance.

\section{REFERENCES}

Berghman LR, van Beeumen J, Decuypere E, Kühn ER, Vandesande F (1988) One-step purification of chicken growth hormone from a crude pituitary extract by use of a monoclonal immuno-absorbent. $J$ Endocrinol 118 , 381-337

Buonomo FC, Sabacky MJ, Della-Fera MA, Baile CA (1987) Effects of somatostatin immunoneutralization on growth and endocrine parameters in chickens. Domest Anim Endocrinol 4, 191-200

Decuypere E, Kühn ER (1984) Effect of fasting and feeding time on circadian rhythms of serum thyroid hormone concentrations, glucose, liver monodeiodinase activity and rectal temperature in growing chickens. Domest Anim Endocrinol 1, 251-262

Denver RJ (1988) Several hypothalamic peptides stimulate in vitro thyrotropin secretion by pituitaries of amiran amphibians. Gen Comp Endocrinol 72, 383-393

Harvey S (1990) Thyroidal inhibition of growth hormone secretion: negative feedback? In: Endocrinology of Birds: Molecular to Behavioural (Wadra M, Ishü S, Scanes CG, eds) Japan Sci Soc Press, Tokyo, 111-127
Harvey S, Baidwan J (1989) Thyrothropinreleasing hormone (TRH)-induced growth hormone secretion in fowl: binding of TRH to pituitary membranes. J Mol Endocrinol 3, 2332

Harvey S, Scanes CG, Klandorf H (1988) Thyrotropin-releasing hormone induces growth hormone secretion in adult hypothyroid fowl. Gen Comp Endocrinol 69, 233-237

lqbal A, Kühn ER, Decuypere E (1989) Somatostatin inhibits thyroxine release from the thyroid gland of chick embryo. Med Sci Res $17,427-428$

Jacobs GFM, Govaerts MP, Vandorpe G, Quaghebeur AML, Kühn ER (1988) Luteinizinghormone-releasing hormone as a potent stimulator of the thyroidal axis in ranid frogs. Gen Comp Endocrinol 70, 274-283

Klandorf H, Sharp PJ, Sterling R (1978) Induction of thyroxine and triiodothyronine release by thyrotrophin-releasing hormone in the hen. Gen Comp Endocrinol 34, 377-379

Kühn ER, Verheyen G, Chiasson RB, Huts C, Huybrechts $L$, Van den Steen $P$, Decuypere E (1987) Growth hormone stimulates the peripheral conversion of thyroxine into triiodothyronine by increasing the liver 5 ' monodeiodinase activity in the fasted and normal fed chicken. Horm Metab Res 19, 304-308

Kühn ER, Decuypere $E$, lqbal $A$, Luysterborgh D, Michielsen A (1988) Thyrotropic and peripheral activities of thyrotrophin and thyrotrophin-releasing hormone in the chick embryo and adult chicken. Horm Metab Res 20, 158162

Kühn ER, Huybrechts $L M$, Vanderpooten $A$, Berghman L (1989) A decreased capacity of growth hormone $(\mathrm{GH})$ receptors and failure of thyrotrophin-releasing hormone to stimulate the peripheral conversion of the thyroxine into triiodothyronine in sex-linked dwarf broiler hens. Reprod Nutr Dev 29, 461-467

Kühn ER, Huybrechts LM, Darras VM, Meeuwis R, Decuypere E (1990) impaired peripheral $\mathrm{T}_{3}$ production but normal induced thyroid hormone secretion in the sex-linked dwarf chick embryo. Reprod Nutr Dev 30, 193-201

Lam SK, Harvey S, Scanes CG (1986) Somatostatin inhibits thyroid function in fowl. J Endocrinol 110, 127-132 
Lauterio TJ, Scanes CG (1988) The role of thyroid hormones in the growth hormone response to protein restriction in the domestic fowl (Gallus domesticus). J Endocrinol 117, 233-238

Licht P, Denver J (1990) Regulation of pituitary thyrotropin secretion. In: Progress in Comparative Endocrinology (Epple A, Scanes CG, Stetson NH, eds) Wiley-Liss, NY, 427-432

May JD (1978) Effect of fasting on $T_{3}$ and $T_{4}$ concentrations in chicken's serum. Gen Comp Endocrino/ 34, 323-327

Meeuwis R, Michielsen R, Decuypere E, Kühn ER (1989) Thyrotropic activity of the ovine corticotropin-releasing factor in the chick embryo. Gen Comp Endocrinol 76, 357-363
Michels $H$, Decuypere E, Huybrechts L, Kühn ER (1986) Endocrinological effects of the sex-linked dwarf gene. IV.TRH sensitivity during growth. In: 7th Eur Poult Cont, Paris 24-28 Aug 1986, 2, 970-974

Scanes CG, Harvey S, Bolaffi JL (1985) TRHstimulation of in vivo $\mathrm{GH}$ release in the domestic fowl. Neuroendocrinology 40, 33-38

Verheyen G, Decuypere E, Kühn ER, Fontaine G, De Groote G (1983) Arrêt de la ponte par induction chez la poule. Effet de différentes méthodes sur certains paramètres de production et sur les concentrations en hormones thyroidiennes, en prolactine en $\mathrm{Ca}, \mathrm{P}$, $\mathrm{Na}$ et en protéines dans le sérum sanguin. Rev Agric 36, 1535-1559 